\title{
Determining the effect of transforming growth factor- $\beta 1$ on cdk4 and p27 in gastric cancer and cholangiocarcinoma
}

\author{
SUNG RYOL LEE ${ }^{1}$, JAE WOOK SHIN ${ }^{2}$, HYUNG OOK KIM ${ }^{1}$, \\ BYUNG HO SON ${ }^{1}$, CHANG HAK YOO ${ }^{1}$ and JUN HO SHIN ${ }^{1}$ \\ ${ }^{1}$ Department of Surgery, Kangbuk Samsung Hospital, Sungkyunkwan University School of Medicine, Jongno-Ku, \\ Seoul 110-746, Republic of Korea; ${ }^{2}$ Department of Biology, Duke University, Durham, NC 27710, USA
}

Received July 26, 2012; Accepted October 16, 2012

DOI: $10.3892 / \mathrm{ol} .2012 .1024$

\begin{abstract}
Gastric cancer and cholangiocarcinoma are problematic throughout the world due to their destructive malignancy. In attempts to treat cholangiocarcinoma and gastric cancer, researchers often explore the effects of transforming growth factor- $\beta 1$ (TGF- $\beta 1$ ). TGF- $\beta 1$ plays a crucial role in causing cell cycle arrest and fibrosis in cancer cells. The present study aimed to identify whether TGF- $\beta 1$ is capable of functioning as an antitumor agent in two cancer cell lines; cholangiocarcinoma and gastric cancer. The downregulation of cyclin dependent kinase (cdk) 4 and the upregulation of p27 were investigated, in order to identify possible antitumor functions of TGF- $\beta 1$. A number of different methods were implemented, including cell proliferation assay, bicinchoninic acid (BCA) assay and western blot analysis with TGF- $\beta 1$, AGS (human gastric cancer cell line) and SUN-1196 (human cholangiocarcinoma cell line). In the AGS study, cdk4 values decreased from 1.000 to 0.670 and then to 0.664 , with increasing TGF- $\beta 1$ concentrations of $0,0.5$ and $5 \mathrm{ng} / \mathrm{ml}$, respectively. By contrast, p27 values increased from 1.000 to 1.391 and then to 1.505 , with increasing TGF- $\beta 1$ concentrations of $0,0.5$ and $5 \mathrm{ng} / \mathrm{ml}$, respectively. In the SUN-1196 study, p27 values increased from 0.548 to 0.807 and then to 0.844 with increasing TGF- $\beta 1$ concentrations of 5,25 and $50 \mathrm{ng} / \mathrm{ml}$, respectively. Certain concentrations of TGF- $\beta 1$ play antitumor roles in gastric cancer through the downregulation of cdk4 and upregulation of p27. Certain TGF- $\beta 1$ concentrations also have antitumor roles in cholangiocarcinoma through the upregulation of $\mathrm{p} 27$. With these results, we
\end{abstract}

Correspondence to: Professor Jun Ho Shin, Department of Surgery, Kangbuk Samsung Hospital, Sungkyunkwan University School of Medicine, 108 Pyung-Dong, Jongno-Ku, Seoul 110-746, Republic of Korea

E-mail: sungryol.lee@samsung.com

Key words: transforming growth factor- $\beta 1$, cyclin dependent kinase 4, p27, gastric cancer, cholangiocarcinoma came a step closer to finding a cure for cholangiocarcinoma and gastric cancer.

\section{Introduction}

Gastric cancer is one of the most common causes of cancerrelated mortality and is responsible for approximately one million fatalities each year (1). Generally a fatal malignancy, gastric cancer is particularly prevalent in East Asian countries such as Korea, China and Japan (2-5). Along with gastric cancer, cholangiocarcinoma causes worldwide concern due to its destructive malignancy. Cholangiocarcinoma has a five-year survival rate of $<5 \%$. The majority of patient fatalities occur within 12 months and $60-70 \%$ of patients have a virtually inoperable condition at the time of diagnosis $(6,7)$. In attempts to identify a cure for such cancers, researchers often explore the effects of transforming growth factor- $\beta 1$ (TGF- $\beta 1$ ). TGF- $\beta$ is a pleiotropic cytokine and a versatile polypeptide. It is involved in a wide range of cellular and genetic activities, including cell proliferation, cell growth inhibition, cell morphology transformation, cell signaling pathway participation and the activation of various types of genes and proteins (8-10). Among the numerous isoforms of TGF- $\beta$ (TGF- $\beta 1$, TGF- $\beta 2$ and TGF- $\beta 3$ ), TGF- $\beta 1$ is widely known for its inhibitory growth effect in angiogenesis and fibrogenesis (11-13). TGF- $\beta 1$ inhibits the growth of nonneoplastic epithelial cells by regulating molecules related to the G1 and S phases of the cell cycle. More specifically, inhibition occurs through upregulation of mito-inhibitors including p15, p21 and p27, and through downregulation of mito-activators including cyclins and cyclin dependent kinases (cdks) (14-17). As cdks dictate cell cycle progression and p27 inhibits cdk activity by preventing the transition from G1 to $S$ phase in the cell cycle (18), the down- and upregulation of these two factors by TGF- $\beta 1$ effectively inhibits uncontrolled cell growth. Through this signaling pathway, TGF- $\beta 1$ plays a crucial role in initiating cell arrest and fibrosis in cancer cells (19-22). In the present study, we aimed to identify whether TGF- $\beta 1$ can function as an antitumor agent in two cancer cell lines; cholangiocarcinoma and gastric cancer. The downregulation of cdk4 and upregulation of p27 was investigated through a number of different methods including 
Table I. Cell proliferation assay for AGS cells.

AGS absorbance

\begin{tabular}{lcccc}
$\begin{array}{l}\text { TGF- } \beta 1 \text { concentration } \\
(\mathrm{ng} / \mathrm{ml})\end{array}$ & 1st trial & 2nd trial & Average & Standard deviation \\
\hline 0 & 0.697 & 0.699 & 0.698 & 0.001 \\
0.5 & 0.714 & 0.734 & 0.724 & 0.014 \\
5.0 & 0.911 & 1.049 & 0.98 & 0.098 \\
25 & 0.7 & 0.834 & 0.767 & 0.095 \\
50 & 0.706 & 0.728 & 0.717 & 0.016
\end{tabular}

TGF- $\beta 1$, transforming growth factor- $\beta$; AGS, human gastric cancer cell line.

Table II. Cell proliferation assay for SUN-1196 cells .

SUN-1196 absorbance

\begin{tabular}{lcccc}
$\begin{array}{l}\text { TGF- } \beta \text { 1 concentration } \\
(\mathrm{ng} / \mathrm{ml})\end{array}$ & 1st trial & 2nd trial & Average & Standard deviation \\
\hline 0 & 0.645 & 0.641 & 0.643 & 0.003 \\
0.5 & 0.611 & 0.615 & 0.613 & 0.003 \\
5 & 0.604 & 0.613 & 0.609 & 0.006 \\
25 & 0.617 & 0.635 & 0.626 & 0.013 \\
50 & 0.675 & 0.718 & 0.697 & 0.030
\end{tabular}

TGF- $\beta 1$, transforming growth factor- $\beta 1$; SUN-1196, human cholangiocarcinoma cell line.

cell proliferation assay, bicinchoninic acid (BCA) assay and western blot analysis.

\section{Materials and methods}

Cells and culture conditions. Recombinant human TGF- $\beta 1$ was provided by R\&D Systems, Inc. (Minneapolis, MN, USA) and was derived from a Chinese hamster ovary cell line with the structure of a disulfide-linked homodimer. The human cholangiocarcinoma cell line (SUN-1196) and human gastric cancer cell line (AGS) were both obtained from the Korean Cell Line Bank (Seoul National University College of Medicine, Seoul, Korea). All cell lines were grown in RPMI-1640 medium (Thermo, Waltham, MA, USA) and were supplemented with glucose, $10 \%$ fetal bovine serum (FBS) and $1 \%$ penicillin/streptomycin. The cells were grown at $37^{\circ} \mathrm{C}$ and $5 \% \mathrm{CO}_{2}$ in an incubator.

The study was approved by the Ethics Committee of Kangbuk Samsung Hospital, Sungkyun-kwan University School of Medicine, Seoul, Korea.

Cell proliferation assay. Cell viability was measured by Cell Viability Reagent (Invitrogen, Grand Island, NY, USA). Cholangiocarcinoma cells (SUN-1196) and gastric cancer cells (AGS) were cultured with recombinant human TGF- $\beta 1$ at concentrations of $0,0.5,5,25$ and $50 \mathrm{ng} / \mathrm{ml}$ for 24 h. PrestoBlue Cell Viability Reagent solution was added to each well, followed by incubation for $2 \mathrm{~h}$. The cell absorbance values were measured with ELISA (Bio-Rad, Hercules, CA, USA) at a wavelength of $570 \mathrm{~nm}$.

Western blot analysis. The protein was extracted from cultured cells using PRO-PREP for Cell/Tissue Protein Extraction Solution (Intron Biotechnology, Sungnam, Korea) and protein concentration was determined by BCA Protein Assay kit (Thermo). For western blot analysis, protein samples $(20 \mu \mathrm{g})$ were subjected to sodium dodecyl sulphate polyacrylamide gel electrophoresis (SDS-PAGE) and then transferred to polyvinylidene difluoride (PVDF) membranes. The membranes were incubated with primary antibodies to cdk4 (34 kDa, 1:2000, rabbit polyclonal; Abcam, Cambridge, UK), p27 (27 kDa, 1:2500, mouse monoclonal; BD Biosciences, Franklin Lakes, NJ, USA) and actin (42 kDa, 1:5000, mouse monoclonal; Abcam). The specific protein was detected by enhanced chemiluminescence (ECL), horseradish peroxidase (HRP) developing agents (AbFrontier, Anyang, Korea) and autoradiography film (GE Healthcare, Amersham, Bucks, UK), while band quantitation was performed with Geliance 600 (PerkinElmer, Waltham, MA, USA).

\section{Results}

Absorbance values of AGS gastric cancer cell lines increases within a certain range of TGF- $\beta 1$ concentrations in a cell 


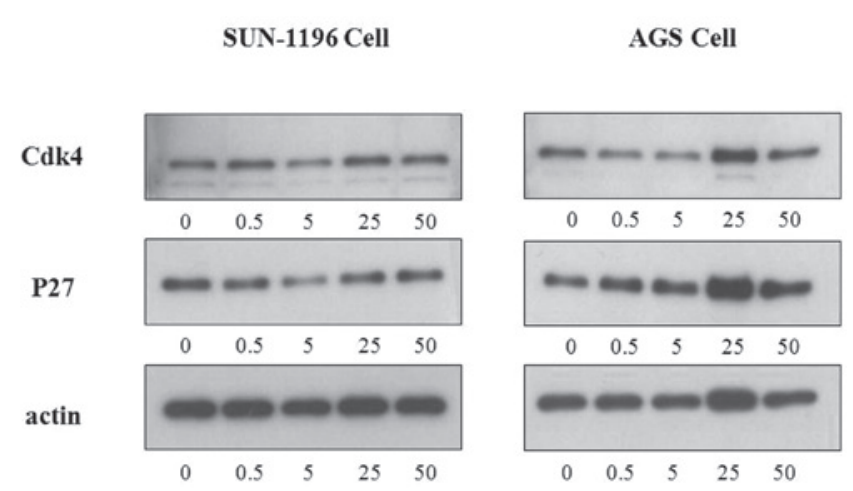

Figure 1. Film detection of protein bands of antibodies by western blot analysis.

proliferation assay. The present study sought to determine changes in absorbance values due to changes in TGF- $\beta 1$ concentration by performing a cell proliferation assay on the AGS cancer cell line. The study aimed to detect patterns in the absorbance value changes that could help identify the effect of increasing TGF- $\beta 1$ concentration on the number of cancer cells remaining following TGF- $\beta 1$ treatment. Since calculated absorbance values are based on the amount of light that remains after being absorbed by cancer cells, the values are good indicators of the number of remaining cancer cells following TGF- $\beta 1$ treatment. The results are shown in Table I. The untreated ( $0 \mathrm{ng} / \mathrm{ml}$ TGF- $\beta 1)$ AGS cancer cell line displayed an absorbance value of 0.698 , which is the average value obtained from two successive trials. The AGS cancer cell line treated with $0.5 \mathrm{ng} / \mathrm{ml}$ TGF- $\beta 1$ displayed a higher absorbance value of 0.724 . Cells treated with $5 \mathrm{ng} / \mathrm{ml}$ TGF- $\beta 1$ had an absorbance value of 0.980 , demonstrating an increase from the previous concentration. The AGS cancer cell line treated with 25 and $50 \mathrm{ng} / \mathrm{ml}$ TGF- $\beta 1$ displayed lower absorbance values, thereby discontinuing the pattern exhibited by the cell proliferation assay. From this result, TGF- $\beta 1$ may potentially regulate gastric cancer metastasis within the concentration range of $0-5 \mathrm{ng} / \mathrm{ml}$.

TGF- $\beta 1$ exerts an antitumor effect on AGS cancer cell lines through cdk4 and p27 pathways. Following the cell proliferation assay, western blot analysis was performed to track the specific pathways through which TGF- $\beta 1$ exerts its antiproliferative effect on AGS cancer cell lines. Three antibodies (cdk4, p27 and actin) were subjected to western blot analysis. Their respective protein bands in each TGF- $\beta 1$ concentration are reproduced in Fig. 1. From Fig. 1, a generally decreasing thickness pattern is evident for cdk4 protein bands, whereas an increasing thickness pattern is demonstrated in p27 protein bands within a certain range. This result is similar to that of the cell proliferation assay performed on AGS cancer cell lines. To ensure uniformity of the western blot analysis, another antibody (actin) was used. The actin protein band thickness indicated whether the values obtained for other antibodies were reliable, as the first three actin bands have consistent thickness for AGS cancer cell lines. From the pattern exhibited by protein bands alone, TGF- $\beta 1$ appears to function through two pathways. In Fig. 2A, cdk4 values decreased from 1.000 to 0.670 and then to 0.664 , with increasing TGF- $\beta 1$ concentrations of $0,0.5$ and
A

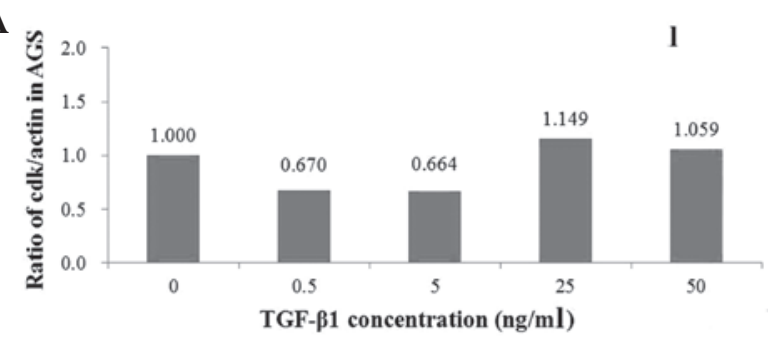

B

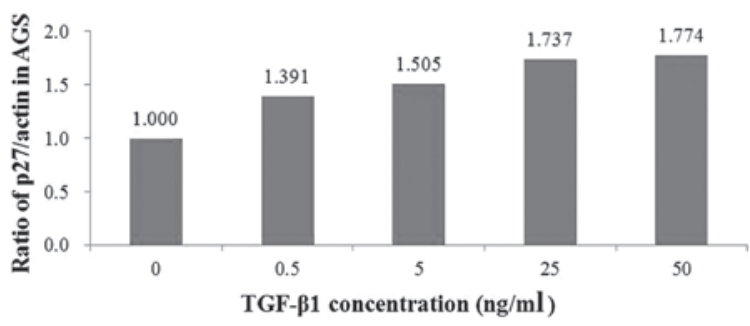

Figure 2. (A) Change in the quantity of $c d k$ with increasing TGF- $\beta 1$ concentration in AGS cells. (B) Change in the quantity of p27 with increasing TGF- $\beta 1$ concentration in AGS cells. TGF- $\beta 1$, transforming growth factor- $\beta$.
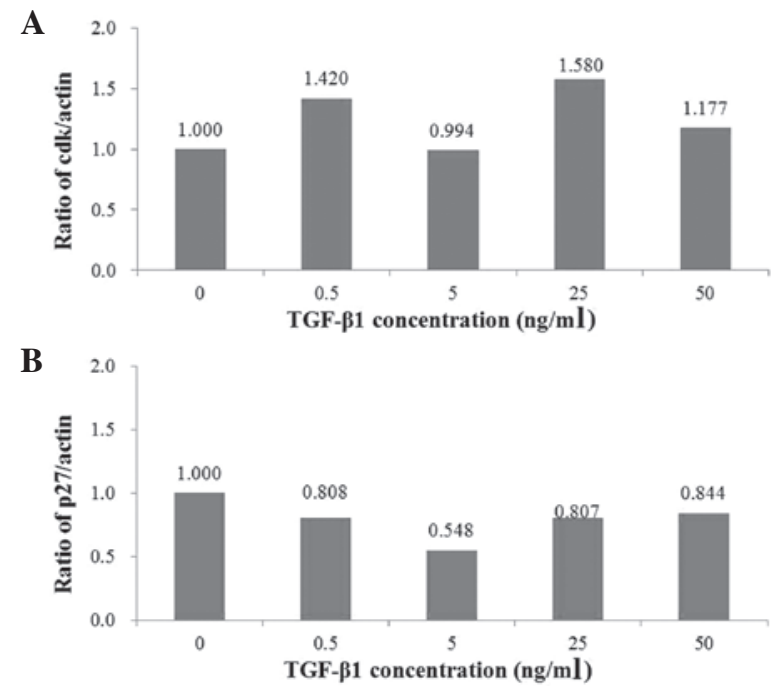

Figure 3. (A) Change in the quantity of cdk4 with increasing TGF- $\beta 1$ concentration in SUN-1196 cells. (B) Changes in the quantity of p27 with increasing TGF- $\beta 1$ concentration in SUN-1196 cells. TGF- $\beta 1$, transforming growth factor- $\beta$.

$5 \mathrm{ng} / \mathrm{ml}$, respectively. From $25 \mathrm{ng} / \mathrm{ml}$ TGF- $\beta 1$, cdk4 values began to increase. In contrast with cdk4, which decreased with increasing TGF- $\beta 1$ concentrations, p27 increased from 1.000 to 1.391 and then to 1.505 with increasing TGF- $\beta 1$ concentrations of $0,0.5$ and $5 \mathrm{ng} / \mathrm{ml}$ (Fig. 2B). Also dissimilar to cdk4, p27 values demonstrated consistent increases, including at 25 and $50 \mathrm{ng} / \mathrm{ml}$ of TGF- $\beta 1$, where p27 values were 1.737 and 1.774 , respectively.

Absorbance values of SUN-1196 cholangiocarcinoma cell lines increase within a certain range of TGF- $\beta 1$ concentrations in the cell proliferation assay. Absorbance values of SUN-1196 cholangiocarcinoma cell lines were measured with a cell proliferation assay. The change in absorbance values displayed increasing and decreasing patterns within certain 
ranges of TGF- $\beta 1$ concentrations. As shown in Table II, SUN-1196 cancer cell lines treated with $0,0.5$ and $5 \mathrm{ng} / \mathrm{ml}$ TGF- $\beta 1$ displayed a decreasing pattern of absorbance values; $0.643,0.613$ and 0.609 , respectively. Cells treated with 25 and $50 \mathrm{ng} / \mathrm{ml}$ TGF- $\beta 1$ displayed an increasing pattern of absorbance values; 0.626 and 0.697 , respectively. This result reveals a potential antineoplastic effect of TGF- $\beta 1$ on cholangiocarcinoma cells within a 5-50 ng/ml concentration range.

TGF- $\beta 1$ exerts an antitumor effect on SUN-1196 cholangiocarcinoma cancer cell lines through the p27 (and not the $c d k 4$ ) pathway. The influence of TGF- $\beta 1$ on SUN-1196 cholangiocarcinoma cancer cell lines was observed by western blot analysis of three antibodies; cdk4, p27 and actin. As is evident in Fig. 1, cdk4 protein bands had indiscriminate thicknesses with increasing TGF- $\beta 1$ concentrations, while p27 protein bands varied in thickness according to a pattern within certain TGF- $\beta 1$ concentration ranges. The actin protein bands had uniform thickness, indicating that the results for other antibody protein bands are reliable. As shown in Fig. 3A, cdk4 values $(1.000,1.420,0.994,1.580$ and 1.177) varied without any distinct patterns. However, Fig. 3B reveals that p27 values decreased from 1.000 to 0.808 and then to 0.548 with increasing TGF- $\beta 1$ concentrations of $0,0.5$ and $5 \mathrm{ng} / \mathrm{ml}$. The p27 values also increased from 0.548 to 0.807 and then to 0.844 with increasing TGF- $\beta 1$ concentrations of 5,25 and $50 \mathrm{ng} / \mathrm{ml}$.

\section{Discussion}

Within a certain concentration range, TGF- $\beta 1$ was revealed to play an antitumor role in two types of cancer; gastric cancer and cholangiocarcinoma. According to the cell proliferation assay results for AGS cancer cell lines, the absorbance values of AGS cells treated with $0,0.5$ and $5 \mathrm{ng} / \mathrm{ml}$ TGF- $\beta 1$ consistently increased. The pattern of increasing absorbance indicates that the number of AGS cells decreased with increasing TGF- $\beta 1$ concentration, as absorbance is measured by detecting the amount of light remaining after being partially absorbed by cells. A higher absorbance value indicates that the machine detected a greater amount of light and the cells absorbed less light, demonstrating that fewer cells are present. Since the absorbance value was highest in AGS cells treated with $5 \mathrm{ng} / \mathrm{ml}$ TGF- $\beta 1$, the smallest number of AGS cells remained in that concentration. This result demonstrated the antitumor role of TGF- $\beta 1$ within a specific concentration range. In short, TGF- $\beta 1$ plays an antitumor role in gastric cancer cell lines when its concentration is between 0 and $5 \mathrm{ng} / \mathrm{ml}$. The western blot analysis results confirmed the aforementioned analysis of the cell proliferation assay and explained the specific pathways through which TGF- $\beta 1$ exerts an anti-neoplastic effect on gastric cancer cells. The unitless cdk4 and p27 in Fig. 2A and $\mathrm{B}$ indicate the quantity of each antibody detected by film detection technique in the western blot analysis. As shown in Fig. 2A, the quantity of cdk4 decreased with an increasing TGF- $\beta 1$ concentration between 0 and $5 \mathrm{ng} / \mathrm{ml}$. As shown in Fig. $2 \mathrm{~B}$, the quantity of p 27 increased with increasing TGF- $\beta 1$ concentration between 0 and $50 \mathrm{ng} / \mathrm{ml}$. These two results confirmed our hypothesis that TGF- $\beta 1$ exerts an antitumor effect on gastric cancer cell lines through the downregulation of cdks (cdk4) and the upregulation of p27. The western blot analysis results were also concordant with the cell proliferation assay results, which suggested that TGF- $\beta 1$ plays an antitumor role in AGS when its concentration is between 0 and $5 \mathrm{ng} / \mathrm{ml}$. The present study demonstrated that TGF- $\beta 1$ exerts an antitumor effect on gastric cancer cells through two pathways, cdk4 and p27, by downregulating cdk4 and by upregulating p27. Bhayal et al revealed that TGF- $\beta 1$ may be a risk factor of genetic susceptibility to gastric cancer in the south Indian population (23). Yuan et al demonstrated that TGF- $\beta 1$ plays an antitumor role in gastric cancer rather than inducing gastric cancer cells to escape human immunological surveillance (24-26). Our results are concordant with those of Yuan et al (24).

As a result of the SUN-1196 cell proliferation assay, another distinct pattern of increasing absorbance data was identified within the TGF- $\beta 1$ concentration range of 5 to $50 \mathrm{ng} / \mathrm{ml}$, which is different from the range found in AGS gastric cancer cell lines. A lower absorbance value indicates that the machine detected less light, thus the SUN-1196 cells absorbed more light. A greater number of SUN-1196 cells remained when retreated with $5 \mathrm{ng} / \mathrm{ml}$ TGF- $\beta 1$, and this number decreased with increasing TGF- $\beta 1$ concentrations of 5, 25 and $50 \mathrm{ng} / \mathrm{ml}$, as indicated in Table II. These results suggest that TGF- $\beta 1$ has an antitumor and anti-proliferative effect on cholangiocarcinoma cells when its concentration ranges from 5 to $50 \mathrm{ng} / \mathrm{ml}$. Fig. $3 \mathrm{~A}$ and $\mathrm{B}$ reaffirmed the antineoplastic influence of TGF- $\beta 1$ on cholangiocarcinoma cells and revealed the pathway through which the antitumor effect is exerted. As with the AGS cell western blot analysis results, the cdk4 and p27 values in Fig. 3 refer to the quantity of antibodies indicated by the thickness of protein bands in Fig. 1. Due the lack of a pattern in the distribution of cdk4 values with increasing TGF- $\beta 1$ concentration (Fig. 3A), we concluded that TGF- $\beta 1$ does not follow the cdk4 pathway and so does not downregulate $\mathrm{cdk} 4$ as was hypothesized previously. However, Fig. 3B revealed a clear pattern of increase in the quantity of p27 within a range of $5-50 \mathrm{ng} / \mathrm{ml}$. This pattern confirmed that TGF- $\beta 1$ exerts an anti-cancer influence via the p27 pathway as was hypothesized. This result was also concordant with the cell proliferation assay, which suggested that TGF- $\beta 1$ is at its most effective as an anti-cancer agent at the concentration range of 5-50 $\mathrm{ng} / \mathrm{ml}$. In brief, TGF- $\beta 1$ has an antitumor effect on cholangiocarcinoma cells through the p27 pathway, but not through the cdk4 pathway. Zen et al demonstrated that TGF- $\beta 1$ did not influence the cell-proliferative activities of three cultured human intrahepatic cholangiocarcinoma (ICC) cells (27). However, the present study revealed that when its concentration is between 5 and $50 \mathrm{ng} / \mathrm{ml}$, TGF- $\beta 1$ has an anti-proliferative effect on cholangiocarcinoma cells. Zen et al also demonstrated that cyclin D1 is key for ICC cells attaining TGF-B1 resistance. However, the present study has demonstrated (by western blot analysis) that through upregulation of p27, TGF- $\beta 1$ is capable of deterring cholangiocarcinoma proliferation, thus nullifying the resistance of cholangiocarcinoma to TGF- $\beta 1$ (27). Furthermore, Shimizu et al revealed that TGF- $\beta 1$ stimulation in ICC results in cellular proliferation. The present study demonstrated that TGF- $\beta 1$ stimulation in cholangiocarcinoma resulted in downregulation of cellular proliferation when TGF- $\beta 1$ concentration was between 5 and $50 \mathrm{ng} / \mathrm{ml}(28)$. 
In conclusion, certain concentrations of TGF- $\beta 1$ play antitumor roles in gastric cancer through the downregulation of cdk4 and the upregulation of p27. These TGF- $\beta 1$ concentrations also have antitumor roles for cholangiocarcinoma through the upregulation of p27. These results bring us a step closer to finding a cure for cholangiocarcinoma and gastric cancer. In future studies, we intend to increase the number of antibodies for western blot analysis, the types of cancer cell being tested and the concentrations of TGF- $\beta 1$. Additionally, PCR will be included to refine our conclusions. With these additions, we may be able to produce more significant results that may further enhance the effort to find a novel cure for cancers.

\section{Acknowledgements}

This study was supported by Medical Research Funds from the Kangbuk Samsung Hospital.

\section{References}

1. World Health Organization. Cancer: Fact sheet N297, February 2009. http://www.who.int/mediacentre/factsheets/fs297/en/. Accessed March 24, 2011.

2. Murray CJ and Lopez AD: Mortality by cause for eight regions of the world: Global Burden of Disease Study. Lancet 349: 1269-1276, 1997.

3. Jemal A, Siegel R, Ward E, Hao Y, Xu J and Thun MJ: Cancer statistics, 2009. CA Cancer J Clin 59: 225-249, 2009.

4. Crew KD and Neugut AI: Epidemiology of gastric cancer. World J Gastroenterol 12: 354-362, 2006.

5. Parkin DM, Bray F, Ferlay J and Pisani P: Global cancer statistics, 2002. CA cancer J Clin 55: 74-108, 2005.

6. Okada T, Sawada T and Kubota K: Rapamycin inhibits growth of cholangiocarcinoma cells. Hepatogastroenterology 56: 6-10, 2009.

7. Shabby Y and El-Serage HB: The epidemiology of cholangiocarcinoma. Semin Liver Dis 24: 115-125, 2004.

8. Massagué J: The transforming growth factor-beta family. Annu Rev Cell Biol 6: 597-641, 1990.

9. Moses HL, Yang EY and Pietenpol JA: TGF- $\beta$ stimulation and inhibition of cell proliferation: new mechanistic insights. Cell 63 : 245-247, 1990.

10. Massagué J, Blain SW, Lo RS: TGF- $\beta$ signaling in growth control, cancer, and heritable disorders. Cell 103: 295-309, 2000.

11. Derynck R, Akhurst RJ, Balmain A: TGF-beta signaling in tumor suppression and cancer progression. Nat Genet 29:117-129, 2001.

12. Löhr M, Schmidt C, Ringel J, et al: Transforming growth factorbetal induces desmoplasia in an experimental model of human pancreatic carcinoma. Cancer Res 61: 550-555, 2001.
13. Bellone G, Carbone A, Tibaudi D, et al: Differential expression of transforming growth factors-beta1, -beta2 and -beta3 in human colon carcinoma. Eur J Cancer 37: 224-233, 2001.

14. Ko TC, Sheng HM, Reisman D, Thompson EA and Beauchamp RD: Transforming growth factor-betal inhibits cyclin D1 expression in intestinal epithelial cells. Oncogene 10: $177-184,1995$.

15. Gene $\mathrm{Y}$ and Weinberg RA: Transforming growth factor beta effects on expression of G1 cyclins and cyclin-dependent protein kinases. Proc Natl Acad Sci USA 90: 10315-10319, 1993.

16. Ravitz MJ and Wenner CE: Cyclin-dependent kinase regulation during G1 phase and cell cycle regulation by TGF-beta. Adv Cancer Res 71: 165-207, 1997.

17. Carneiro C, Alvarez CV, Zalvide J, Vidal A and Domínguez F: TGF-beta1 actions on FRTL-5 cells provide a model for the physiological regulation of thyroid growth. Oncogene 16: 1455-1465, 1998.

18. Luo J, Chen YJ, Wang WY and Zou SQ: Effect of mutant p27(kip1) gene on human cholangiocarcinoma cell line, QBC(939). World J Gastroenterol 14: 5344-5348, 2008.

19. Czaja MJ, Weiner FR, Flanders KC, et al: In vitro and in vivo association of transforming growth factor-beta1 with hepatic fibrosis. J Cell Biol 108: 2477-2482, 1989.

20. Bissell DM, Wang SS, Jarnagin WR and Roll FJ: Cell-specific expression of transforming growth factor-beta in rat liver. Evidence for autocrine regulation of hepatocyte proliferation. J Clin Invest 96: 447-455, 1995.

21. Ichikawa T, Zhang YQ, Kogure K, et al: Transforming growth factor beta and activin tonically inhibit DNA synthesis in the rat liver. Hepatology 34: 918-925, 2001.

22. Yata Y, Gotwals P, Koteliansky V and Rokey DC: Dosedependent inhibition of hepatic fibrosis in mice by a TGF-beta soluble receptor: implications for antifibrotic therapy. Hepatology 35: 1022-1030, 2002.

23. Bhayal AC, Prabhakar B, Pandu K, et al: Role of transforming growth factor- $\beta 1-509 \mathrm{C} / \mathrm{T}$ promoter polymorphism in gastric cancer in south Indian population. Tumor Biol 32: 1049-1053, 2011.

24. Yuan XL, Chen L, Zhang TT, et al: Gastric cancer cells induce human $\mathrm{CD} 4+\mathrm{Foxp} 3+$ regulatory $\mathrm{T}$ cells through the production of TGF- $\beta 1$. World J Gastroenterol 17: 2019-2027, 2011.

25. Shevach EM: Mechanisms of foxp3+ T regulatory cell-mediated suppression. Immunity 30: 636-645, 2009.

26. von Boehmer H: Mechanisms of suppression by suppressor T cells. Nat Immunol 6: 338-344, 2005.

27. Zen Y, Harada K, Sasaki M, et al: Intrahepatic cholangiocarcinoma escapes from growth inhibitory effect of transforming growth factor-beta1 by overexpression of cyclin D1. Lab Invest 85: 572-581, 2005.

28. Shimizu T, Yokomuro S, Mizuguchi Y, et al: Effect of transforming growth factor-beta1 on human intrahepatic cholangiocarcinoma cell growth. World J Gastroenterol 12: 6316-6324, 2006. 